\title{
REFORMING CORPORATE GOVERNANCE VIA LEGISLATION IN THE UNITED STATES - THE CASE OF THE SARBANES-OXLEY ACT**
}

Summary: $\quad$ The scope of this paper is to evaluate the Sarbanes-Oxley Act from a legislative theoretical point of view with the aid of showing some theories on legislation, a field which came to the forefront of jurisprudence in relatively recent times in Anglo-American jurisprudence. The intention is to show that Sarbanes-Oxley Act was a piece of suboptimal legislation, by comparing and contrasting it to some normative theories.

Keywords: $\quad$ Sarbanes-Oxley Act, optimal-legislation, law-making, efficiency of law, efficacy of law

\section{INTRODUCTION}

The aim of the paper is to analyse legislation as an instrument for reforming corporate governance. Owing to its importance, the Sarbanes-Oxley Act was chosen as the subject for the analysis. Despite its bi-partisan support in the Congress, the opinions on the Act have never been unanimous, for different reasons. The Republicans claim the Act was highly restrictive towards smaller businesses, punishing them unfairly for the transgressions of the major corporations involved in the large-scale scandals of 2002. Meanwhile, the Democrats criticised the Act for being too lenient, as it did not contain too many novelties. This division can also be observed in the evaluation of the Act by the academia.

To find out the justification of the differing opinions, it is important to give a legislative-minded analysis of the Act. Therefore, the paper firstly wishes to briefly introduce the historical background. For that, it is important to recall some of the major events of the era. Secondly, the legislative process itself is reviewed. It is important to overview what happened in both houses of the Congress, as it gives us the relevant understanding of the political climate. The third part of the paper wishes to analyse the Act and its genesis with the help of some theories

\footnotetext{
* András Kecskés, PhD, Associate Professor, Department of Business and Commercial Law, Faculty of Law, University of Pécs. H-7622 Pécs, 48-as tér1., Hungary. E-mail address: kecskes.andras@ajk.pte.hu. ORCID: http://orcid.org/0000-0001-6158-2049.

** Supported by the ÚNKP-17-4-IV New National Excellence Program of the Ministry of Human Capacities.
} 
on legislation. Only through that can a scientifically sound understanding of the shortcomings of the Act can be obtained.

\section{HISTORICAL BACKGROUND OF THE SARBANES-OXLEY ACT}

To understand the events during the legislation of the Act, it is essential to briefly overview the factors which led towards its creation. By 2002 the general exuberance which defined the capital markets of the late 90s was long gone. The bursting of the dot-com bubble and the emerging corporate scandals - WorldCom, Adelphia, Tyco and Enron - has completely eroded the public trust in the market and undermined the trust towards the government, and the various agencies tasked overseeing the market.

The reason for the corporate scandals was numerous. First of all, excessive optimism made investors overly confident, thus they did not exercise caution in their dealings. This resulted in the dot-com bubble, for example, a phenomenon sparked by the sudden interest in IT sector and prospects it promised. However, exuberance was also mixed with corporate greed. The remuneration schemes rewarded CEOs and other members of the management generously. ${ }^{1}$ The switch to performance-based pay while also giving shares made the less scrupulous management more interested in short-term profits instead of sustainability. To make matters worse, due to the complicated agent-principal conflict between the gatekeepers (such as auditors ${ }^{2}$ and attorneys), which made them dependent on each other, the interest of the shareholders and stakeholders were also neglected in favour of serving the interest of the management of the very company they were supposed to monitor. ${ }^{3}$ On $11^{\text {th }}$ September 2001, the terrorist attack on the World Trade Center created an environment of uncertainty and paranoia. This all could be seen in the way stock markets performed; the government and the legislature realised that something had to be done to restore public confidence. ${ }^{4}$

President George W. Bush announced his 10-point program in the beginning of 2002 in which three key factors were identified for the corporate debacle: the lack of reliable information for investors, the lack of accountability for corporate officers and the failure of the audit system. ${ }^{5}$

1 Zéman, Z.; Gacsi R.; Lukács J.; Hajós L., Management control system in banks, BIATEC, Vol. 21, No. 6, 2013, pp. 14-17 (2013).

2 For some aspects of the auditing profession, see Bárczi J.; Zéman Z.; Tóth M.; Széles Zs.; Key indices of financial controll, Journal of International Scientific Publication: Economy and Business Vol. 2, No 1. Lentner, Cs., A pénzintézetek társadalmi felelősségvállalásának új dimenziói és a könyvvizsgálat szerepe, Számvitel adó könyvvizsgálat: szakma Vol. 53, No.7-8, 2011, pp. 348-350.

3 Regarding corporate social responsibility issues in the financial sector see Lentner Cs.; Szegedi K.; Tatay T., Corporate Social Responsibility in the Banking Sector, Pénzügyi Szemle/Public Finance Quarterly Vol. 60, No. 1, 2015, pp. 95-103.

4 See Kecskés A.; Halász V., Stock Corporations A Guide to Initial Public Offerings, Corporate Governance and Hostile Takeovers, HVGORAC-LexisNexis, 2013, pp. 201-202.

5 See The President's 10-Point Plan - Improving Corporate Responsibility And Protecting America's Shareholders Wall Street Journal March 6, 2002, http://www.wsj.com/articles/SB1015460971646141720. Accessed October 5, 2015. 


\section{LEGISLATION PROCESS}

The Sarbanes-Oxley Act came into force on 30th July 2002 when it was signed into law by President George W. Bush. It is widely known it enjoyed a widespread -bipartisan- support. Rep. Michael Oxley's draft was adopted by the House on 25th April 2002 by a vote 334to 90, whereas the Senate Banking Committee approved it on 18th July 2002 by a vote 17:4. On 15th July 2002 (3 weeks after the Worldcom scandal broke) the Senate unanimously, by a vote 79 to 0 , adopted the bill. Afterwards, the conference committee formed by the House and Senate reconciled the two bills and on 25th July the conference bill was approved, which was given the name Sarbanes-Oxley Act of 2002. On the next day the bill passed with a landslide majority - by a vote 423 to 3 in the House and 99 to 0 in the Senate. ${ }^{6}$

The bill was introduced to the House by Michael Oxley on 14th of February 2002, originally co-sponsored by 24 other Republican representatives. Committee sessions on the bill did not start until the 13th of March. Afterwards, there were three committee hearings on the matter. Provisions of the bill could be summarised the following way: first and foremost, it set out the creation of an oversight board for the accounting profession ${ }^{7}$; secondly, it appropriated more funds for the Securities Exchange Commission ${ }^{8}$ and thirdly, it made a proposal for a series of government-sponsored studies about various corporate governance-related subjects. ${ }^{9}$

The House Republicans praised the bill, claiming it was a milestone in corporate legislation. ${ }^{10}$ On the other hand the bill was criticised for being too lenient on corporate wrongdoers as the provisions were mainly restatements of existing law; as the press of the time put it the bill was merely "punting" the responsibility ${ }^{11}$ to the Securities and Exchange Commission which according to the opponents of the bill - was exactly what the accounting profession wanted all along. ${ }^{12}$ Another criticism was that the bill did not even satisfy the criteria set out in President Bush's 10-point program..$^{13}$ The Republicans defended their position by claiming that not only corporate scandals are far more complex than they appear and thus, legislation should neither be too hasty nor too strict, but also the corporate scandals are far and few between, thus a whole sector should not be penalised for the actions of a few. ${ }^{14}$ Nevertheless, the Republican bill got approved by a healthy margin, enjoying a bipartisan support; due to the imminent re-election campaign; which meant the Democrats could not risk rejecting the Republican bill on the grounds of being too lenient while also having supported a failed alternative before. ${ }^{15}$

\footnotetext{
6 See Kecskés; Halász, op.cit. note 1, p. 202.

7 See H.R 3763. Section 2. as engrossed in House (04/24/2002).

8 See 148 Cong. Rec. 2002 H1541 April 24 (statement of Mr Sessions).

9 See H. R. 3763 Section 14-19. as Engrossed in House (04/24/2002).

10 See 148 Cong. Rec. 2002 H1541 April 24 (statement of Mr Sessions).

11 Borzán A.; Lentner Cs.; Szigeti C., A pénzügyi vállalkozások felelősségvállalásának új dimenziói 2011 Economica (Szolnok) Vol. 4, No. 11, 2011, pp. 22-30.

12 See 148 Cong. Rec. 2002 H1546 April 24 (statement of Mr Kanjorski) and 148 Cong. Rec. 2002 1, 548 April 24 (statement of Mr Jones).

13 See 148 Cong. Rec. 2002 H1546 April 24 (statement of Mr LaFalce).

14 See 148 Cong. Rec. 2002 H1552 April 24 (statement of Mr Ferguson).

15 See Romano R., The Sarbanes-Oxley Act and the Making of Quack Corporate Governance, Yale Law Journal, Vol. 114, No. 7, 20042005, p. 1551.
} 
The Senate received the engrossed bill ${ }^{16}$ from the House on $25^{\text {th }}$ April 2002 and on the same day it was referred to the Committee on Banking, Housing, and Urban Affairs of which the chairman was Paul Sarbanes. Yet the bill was not passed until 15th July. The main reason for the delay was the shifts in the public mood: in the autumn of 2001 the fall of Enron temporarily stirred up the public spirit. By next April, the crisis mood became more languid as the popular opinion held that it was only an isolated phenomenon. ${ }^{17}$ The bill was only plodding forward: it took a month for Sarbanes to acquire support from both parties. The resulting situation caused a serious headache for Senate Majority Leader Thomas Daschle; the success of the bill seemed unattainable. As of 26th June, however, on the day the Worldcom scandal broke, there was a drastic change in the political climate. Suddenly the public focus shifted back to corporate abuses again, which put Republicans under pressure. Now Daschle could hope for eighty supporting votes on the voting in July. Not even Republican senator Phil Gramm the ranking member of the committee, who was the staunchest opponent of the bill, tried to oppose it. ${ }^{18}$

The popular belief holds that the most important questions of law-making in the USA are decided in the committee sessions. In many cases, however, the most important events are taking place in the Senate chamber, as the rules of procedure grant a wide-range of means to affect legislation; in certain cases, they may resort to filibuster to slow down the process. ${ }^{19}$

However, a successful cloture can deeply impact the procedure as it restricts further debates and amendments to the bill. This can only be achieved by a bipartisan agreement, as this motion requires the $3 / 5$ th of votes in the Senate..$^{20}$

The success of cloture was especially important in the case of the Sarbanes-Oxley Act. Making this piece of legislation would have required the support of more than a $3 / 5$ th of the Senate, which would have been hard to achieve, as there were 122 amendments proposed. Notwithstanding, the success of the cloture meant that unresolved issues from the committee sessions never made it into the Senate, thus there was no opportunity for a detailed examination of the regulations set out in the bill in this phase.

While the bill was presented by the Democrats, its content was also influenced by the Republicans, as the success of it depended on their support. Since the Democrats only had a one-vote majority in the Senate, ${ }^{21}$ support from both parties were required for the success of any sort of legislation.

16 When a chamber agrees on a bill, the Enrolling Clerk prepares the final version which contains the amendments. It is printed on a blue paper which then gets sent to the Senate. Technically, an engrossed bill should be referred only as an Act, but it is common to use "bill" consistently. See House of Representatives, How Our Laws are Made: Revised and Updated, US Government Printing Office, 2007, p. 36-37.

17 See Kim B. Recent Developments, Harvard Journal on Legislation, Vol. 40, No. 1, 2003, p. 238.

18 See Romano, op. cit., note 15, p. 1558.

19 See ibid. 1554.

20 See House of Representatives, note 16 p. 40.

21 Originally both the Democrats and the Republicans held 50-50 seats in the Senate, but in 2001 Vermont Republican James Jeffords left the Republican Party to go Independent and he joined the Democratic Party's caucus. See: United States Senate, Senate History 1964-Present The Unforgettable 107th Congress http://www.senate.gov/artandhistory/history/minute/ unforgettable-107th-congress.htm (October 5, 2015). 
Owing to the Republican influence, there must be at least two chartered accountants in the Public Company Accounting Oversight Board (PCAOB) as Republican Senator Michael Enzi, ${ }^{22}$ the sole chartered accountant in the Senate, took special care to ensure their participation of the active accountants. His support was crucial, which depended on whether the aforementioned provisions would be included or not.

It can be seen from the reports on the committee sessions that Senator Paul Sarbanes was only able to submit a proposal by the end of May which could be agreed on by all the democratic members of the committee, and working out a deal with Michael Enzi took him another month. Enzi's conversion brought the support of his fellow party members, thus Sarbanes' bill could be passed by a bipartisan -but not unanimous- vote. Even though the Republican members had submitted more than a hundred amendments to slow down the process, the deal with Enzi provided Sarbanes the opportunity for ignoring those.

The Republicans changed tactics in the next phase of legislation. While during committee sessions they took the opposing stance to the bill, their movement to cloture in front of the Senate virtually enabled the passing of the act. They justified their radical change of heart with claiming they would have more leverage over the process in the upcoming conference committee sessions, where the House and the Senate bills would be reconciled.

It is more likely they altered their stance because of the almost crisis-like change in political and popular mood. All the relevant political analyses concluded that crises are calling for quick and definite measures in legislation.

Due to the crisis, the Senate sped up the legislation and voted in favour of the cloture.

Three amendments were made on the floor, which gave additional substance to the legislation. The first was about the prohibition of non-auditing services provided by auditing firms, the so-called "Leahy-amendment", and thirdly, the prohibition on executive loans.

The House bill contained no provisions about the organisational matters of the monitoring committees in order to allow the Securities Exchange Commission (SEC) to define them. ${ }^{23}$ Providing non-audit services was restricted by the SEC before, to which the House bill added two more restrictions. ${ }^{24}$

The source of disagreement was the Republican support for the House bill, which happened to coincide with the proposal made by Harvey L. Pitt, the chairman of the SEC at that time. His proposal was also favoured by the auditors - and through that the House proposal. However, a few years before the auditors, with the aid of Pitt, managed to obstruct the regulatory intentions of Arthur Levitt, the then-chairman of the SEC. Pitt's person, who enjoyed the support of Republicans and the ire of Democrats ${ }^{25}$ was a definite factor in both parties

\footnotetext{
22 Senator Michael Enzi participated in the legislation as a member of the Committee on Banking, Housing and Urban Affairs.

23 See H. R. 3673.

24 See ibid.

25 Harvey L. Pitt's person was heavily contested due to his past at major accounting and law firms. On October 22, 2001, not too long after he was appointed as the head of the Securities Exchange Commission, he remarked that his intention was to make SEC a "kinder and gentler place for accountants". See Jeanne Cummings - Yochi Dreazen - Michael Schroeder 2002: SEC Chairman Pitt Resigns Amid Webster Controversy The Wall Street Journal November 6. http://www.wsj.com/articles/ SB1036548136249093108 (October 5, 2015).
} 
opinion. It is possible that Democrats might have held different views on certain questions had a different person presided over SEC.

The debate on prohibiting non-audit services evoked the clashes of two years ago between Levitt and the auditors. What might have been an unwarranted concern back then; in 2002 it became a well-founded foresight - at least according to the Democrats. Owing to the public outcry and the media frenzy elicited by the accounting fraud, politics came under pressure as well. Between January and July 2002, the headlines in the leading evening news programmes had 613 news items regarding business, out of which 471 (77\%) were about the accounting fraud. Out of those, $80 \%$ were calling for action from the government. This greatly undermined the auditors' prestige in society. ${ }^{26}$

Hardly any attention was given to three important corporate governance issues, namely the independence of audit committees, executive loans, and certification requirements. The most well-known initiative from the latter category was made by Senator John McCain and Carl Levin. It was about the accounting evaluation ${ }^{27}$ of stock exchange options, which did not make it into the bill due to the lack of support from the party leadership. This should not be taken as a sign of discord, however, the reason was more practical: the initiative could have obstructed legislation. Even Sarbanes gave up on the regulations regarding stock exchange options to acquire the support of his party.

Eventually, it was the statute of limitations which served the basis for that Republican move resulting in the cloture: Senator Gramm motioned for the separation of it from the other provisions, which jeopardised the success of the bill. Thus, the parties agreed on both the statute of limitations and the cloture. ${ }^{28}$

During the short period between the cloture and the passing of the bill, the Senate adopted a few amendments, including one about the prohibition of personal loans to executives ${ }^{29}$. This amendment - initiated by Democratic Senator Charles Schumer - was adopted undisputed and unanimously. It is remarkable that only a few days before President George W. Bush, in his speech delivered in Wall Street, called for boards to refrain from providing such loans. ${ }^{30}$ Schumer otherwise remarked in his statement that he spoke to the White House and he secured their support. ${ }^{31}$

The American jurisprudence discusses this with biting criticism, as they are not sure why President Bush took such a stance in this matter when earlier he received such loans. It was argued that he was trying to distance himself from such criticism. ${ }^{32}$ Whatever the reason may be, President Bush's attitude proved to be decisive regarding the fate of the provision. Beforehand, the Banking Committee rejected such proposal; even Senator Sarbanes, when he was

\footnotetext{
26 Romano, op. cit., note 151562.

27 Regarding accounting policies and their role in aiding decision-making see: Lukács, J., Tóth, M., Zéman Z., A számviteli politika döntéstámogatásának modellezése ágazati mátrix fejlesztéssel Gazdaság és társadalom Vol. 12, No. 3-4, 2012, pp. $106-117$. 
presenting his bill in the Senate, said that his commission had not even gone as far as prohibiting executive loans. ${ }^{33}$

For a law to be considered to be passed both chambers must adopt the bill with identical texts. If there are any differences in the text adopted then there are two possible ways of reconciliation. It can either be sent back to the other chamber to have it reconsidered and amended according to the proposed text of the other bill. The other chamber could still propose amendments in their counterproposal. This process is called as the amendment exchange or "ping-pong". It can be a rather lengthy process, but the political climate was calling for a swift solution. Thus, that is why a conference committee was requested. A conference committee is an ad-hoc committee formed in relation to a piece of legislation with the purpose of reconciling the difference between the resolutions of both chambers. ${ }^{34}$ The mere difference between texts is not enough for requesting a conference committee, though. It is required that one House must amend and then adopt the bill of the other House. ${ }^{35}$

The result of the conference committee was that everything was struck out from the House Bill underneath the enacting provision and it was completely replaced by the text of the Senate bill. $^{36}$

\section{ANALYSIS OF THE SARBANES-OXLEY ACT}

Before evaluating the Sarbanes-Oxley Act, it is important to the gain further insight to some of the theories regarding legislation. Both the Anglo-American and European viewpoints need to be considered for a well-rounded overview of the Act. One interesting aspect of the topic at hand is that the Anglo-American jurisprudence seems to be lagging the Europeans. Ever since the 1970's (and perhaps even earlier) when German jurisprudence started to pay attention to the alarming tendencies such as the increasing number of laws being made which often came at the expense of their quality; ${ }^{37}$ there have been numerous attempts made to understand legislation.

Meanwhile, the major rift between Anglo-American and Continental jurisprudence could be explained by Robert B. Seidman's ${ }^{38}$ observation: for a long time [common-law] court decisions have been the primary source of law instead of legislation which made them "myopically fixated on the judicial role." ${ }^{39}$ On the other hand, for Continental lawyers (meaning most of

33148 Cong. Rec. S6332 July $8^{\text {th }}$ (statement of Senator Sarbanes).

34 Library of Congress: The Legislative Process: Resolving Differences Congress.gov https://www.congress.gov/legislative-process/ resolving-differences Accessed on October 5, 2016.

35 See House of Representatives, op. cit., note 16, p. 42.

36 See House of Representatives: Conference Report July 24, 2002. (H. Rept. 107-610) 69.

37 See Hill, H., Einführung in die Gesetzgebungslehre, C. F. Müller Juristicher Verlag Heidelberg 1982, p. 2; Schulze-Fielitz, T., Theorie und Praxis parlamentarischer Gesetzgebung, Duncker \& Humblot. Berlin, 1988. 1. both cited by Drinóczi, T.; Petrétei, I., Jogalkotástan, Dialóg-Campus Kiadó, Pécs, 2004, p. 17.

38 Robert B. Seidman is a Professor of Law and Political Science at Boston University.

39 See Seidman R., Justifying Legislation: A Pragmatic, Institutionalist Approach to the Memorandum of Law, Legislative Theory, and Practical Reason, Harvard Journal on Legislation, Vol. 29, No. 1, 1992, p. 76. 
the Roman-Germanic legal families) legislation has always served as the primary source of law. This means there was more of an incentive for lawyers and jurisprudence to actually look into the way laws are made and to create a basis for principled legislation. For example, in Prussia and the Austrian part of the Habsburg empire, before the introduction of large-scale civil codes (Allgemeines Landrecht and Allgemeines Bürgerliches Gesetzbuch respectively), major preparatory works were undertaken (such as partial introduction, to test the real the world application of the codex) in order to ensure that legislation met its intended goals. ${ }^{40}$ Yet, we cannot regard these actions as the application of principled legislation theory, due to the fact that none of those countries was something one may call as states under the rule of law.

Legislation itself is important in a modern (constitutional) democracy; it is the exercise of power constituted by the fundamental law. ${ }^{41}$ Its importance lies in the ability to intervene in social and economic processes to aid the stability and development. This power is not unlimited, however. There are all sorts of rules and procedures which are aimed at keeping up the democratic nature of legislation, to ensure the public good prevails.

The main characteristic of legislation is that it is always a conscious activity with the aim of influencing future behaviour of a large number of addressees -unlike judge-made law, as the decision of the judge is only binding inter se, and not towards the general public. This also means that legislation itself is a deliberate and willing activity. One cannot legislate accidentally, but legislation might have unintended consequences. This is the main reason why legislators must work according to plan and it is important for them to utilise scientific ${ }^{42}$ methods. ${ }^{43}$

Optimal legislation ensures the efficacy and efficiency of law. If the legislation is sub-optimal, the efficacy and efficiency suffer. Thus, based on what has been said above, the legislators must always ensure their legislation is as optimal as possible. The usual pitfalls which make suboptimal legislation are the following:

- lack of clarity

- duplicity

- improper identification of the underlying issue

- not allocating enough resources for the execution

- political overloaded nature of the debate. ${ }^{44}$

Justification lends moral authority to the law which is essential for the efficacy of law as the end product is more likely to be observed by the addressees. It must be emphasised that optimal legislation is always justified. So, when it comes to the evaluation of laws, it is important to study whether there was any compelling reason to the action of the law-maker, and how well it would be received by the intended addressees.

\footnotetext{
40 See Visegrády Antal: The Influence of Jerzy Wróblewski on Hungarian Legal Theory, Prawo I Politika 7. 96.

41 See Drinóczi; Petrétei, op. cit., note 37, p. 73.

42 One must never underestimate the importance of involving the legal science in filling gaps in legislation. For example in the USA, the American Law Institute's work is invaluable at collecting and processing legislation, judgments and scientific results. See Sándor, I., A bizalmi vagyonkezelés és a trust, HVG-Orac, Budapest, 2014, p. 233. 


\section{THE ANGLO-AMERICAN JURISPRUDENCE ON LEGISLATION}

Most of the Anglo-American legal theoreticians are still highly influenced by the sovereign theory of Bentham, and Locke or Austin's command theory. ${ }^{45}$ While their theories provide explanation about authority of laws, they do not really explain the reality of law-making: laws are treated as something static that have always been there or as if they came from one actor; 46 and thus instead the focus is shifted towards the application of the law.

Some of the legal positivists, such as Hart, were also interested in the way legislation worked. According to Hart, the legislature is nothing like Austin's model of "uncommanded commanders", as they are a product of society's recognition. This is demonstrated by the fact that legislative bodies are pretty much created by rules such as the Constitution, and their rules of procedures are also imposing limits on their activities. Thus, unlike a true sovereign, the legislature does not have unlimited powers and cannot be unlimited by itself. However, it must be also noted that Hart himself was not quite interested in the legislature as the "sort of body it was". ${ }^{47}$

In his 1995 essay “The Dignity of Legislation”, Jeremy Waldron ${ }^{48}$ laid out the framework for a new kind of legislation theory which takes into account the political realities of legislation as well. He proposed that the "one-sovereign" model is insufficient, as modern legislative bodies are usually made up of multitudinous members, each with their own personal bias and agenda, thus legislation theory must not treat legislation as a "black box"49 from which laws emanate from. He claims that the democratic legislation bases its final authority on the fact that its laws are created by a large popular assembly. He also argues that modern jurisprudence, especially American jurisprudence has a rather unattractive view on legislation, which claims that it is nothing more than "deal-making", "log-rolling", "interest-pandering" etc. instead of principled legislation..$^{50}$ This does not mean, however, that a normative theory of legislation should not be created, however, he points out that this theory should not be aimed at the legislators only, as in telling them "how they ought to behave, what laws they ought to pass, what criteria they should use for the public good, how much attention they should pay to their constituent's interests (...)" but a theory that also addresses the intended audience of the laws such as the general public or the judiciary body. ${ }^{51}$ He believes that the democratic authority of the legislator, the textual quality of legislation and the authority of both are intertwined. ${ }^{52}$

Seidman is taking a pragmatic, institutionalist approach towards legislation. He states that the point of a legislative theory is to guide the legislature and not creating an ideal type of legi-

45 Mainly applies to Anglo-American jurisprudence.

46 See Waldron J., The Dignity of Legislation, Maryland Law Review, Vol. 54, No. 2, 1995, pp. 646-647.

47 See ibid. pp. 642-643.

48 Jeremy Waldron is a Professor of Law, Jurisprudence and Social Policy Program, School of Law (Boalt Hall), and Professor of Philosophy, University of California at Berkeley. 
slation for the academia. ${ }^{53}$ When it comes to legislation in modern democracies, it is essential that it can be always justified as the sovereignty of legislature in itself is simply not enough. ${ }^{54}$ Justification comes from "practical reason" which according to him is nothing but reason informed by experience. He rejects the justification by personal interests or power play. The addressees of legislation theory are the drafters, which include both the people creating the text and the so-called "investigators" whose task is finding the relevant facts. Justified legislation to him is about remedying social problems which are repeatedly emerging. In order to do so, all the necessary information must be gathered. In his theory, he outlines the methodology theory to be applied. He rejects the "ends-means" methodology, which does not allow empirical research of the critical aspect of decision-making as it only cares about the objectives, ${ }^{55}$ and the "incrementalist" approach, which denies the possibility of undertaking radical changes via legislation. He aptly refers to that approach as "muddling through" ${ }^{6}$ Instead, he put problem-solving in the forefront. According to him, one must not forget about the importance of a "Grand Theory" - which is the overarching belief system of the legislator- that affects the language and the perception of the given problem at hand. The importance of conducting a thorough research was nominated as a key element in justified legislation. This means the examination and the evaluation of the already existing laws, the constraints and the resources regarding the addressee. He advocates the institutionalist approach as Seidman states that the addressee's behaviour is largely affected by the by the implementing agencies. ${ }^{57} \mathrm{He}$ also expressed his dismay at the current state of American legislation; he states on the state level the memoranda of legislation are often missing and he does not paint a rosy picture of federal legislation either. Memoranda can be likened to the way a judge justifies his or her own decision, which gives moral authority of the judgment delivered. However, if there is no way one can retrace the thought process then it is more than likely to erode the authority of legislation. ${ }^{58}$

\section{EUROPEAN THEORIES ON LEGISLATION}

Another attempt at creating a coherent legislation theory was Luc Wintgens' idea of what he called as "legisprudence". He argued that the development of legislation theory was stunted by what he called as "legalism". He claimed that by separating law and politics obliterates the practical reason on legislation, as they take laws something that has always been there. Thus, the legalist approach always concentrates on the application of law only. This sort of thinking in his view impedes any further discussion on the rationality and the justification of legislation, which in turn makes it much harder to discuss optimal legislation. Thus, he proposes that legislation as the end-product must be separated from legislation as the process. He also states that legislation under legisprudence principles is "a rational, principled theory of

\footnotetext{
53 See Seidman, op. cit., note 36, p. 4

54 See ibid. pp. 19-20.

55 See ibid. pp. 29-31.

56 See ibid. pp. 31-32.

57 See ibid. $56 \mathrm{f}$.

58 See ibid. p. 3.
} 
legislation" 59 , where norm givers are not only political actors but also legal actors as well. Thus, law-making in his words is more than a "power game". And because of that he also prescribes duties for the lawmaker, such as the duty

- of relevant-fact finding,

- of problem formulation,

- of weigh and balance alternatives,

- to prospection,

- to take future circumstances into consideration,

- to monitor the issued norms,

- to retrospection,

- to review. ${ }^{60}$

Thus, legisprudence seems to be more aimed at the legislator, rather than intended addressees or the institutions, unlike Waldron's or Seidman's proposed theory. Wintgens' starting point is that individuals are basically free, and legislation is the act of giving up those freedoms when they consider that they cannot effectively control that particular relation just by the basing their actions on their freedom. This is what he calls as the replacement of the "conception of freedom" with the "conception about freedom" ${ }^{61}$

Wintgens' proposed legisprudence theory heavily relies on the practical justification of legislation, which is built on four major principles. The first one is the principle of coherence, which requires legal norms to be viewed as a whole within the legal system. This means that each norm must make sense within the whole system. The second principle is the principle of alternativity, which means that legislation (a conception about freedom) must be a justified alternative to "failing social interaction". The third principle is called the principle of temporality. This means that the justification of legislation may become obsolete as the time passes. A norm which made sense ten years ago might be insufficient later. Thus, he argues that legislation should not only be justified at the moment it was issued, but also needs to retain its justification over time. ${ }^{62}$

Jerzy Wróblewski ${ }^{63}$ argues that for optimal legislation three fields must be considered. Firstly, he identifies an axiological level, which he describes as the harmony between the theoretical and the instrumental evaluation in order to reach the socially most appropriate resolution. Since Wróblewski's writing style can be considered extremely succinct and dense, it is advisable to give a few examples to demonstrate his ideas. In Hungary, for example, the Parliament has two chief instruments to use for legislation. One is the creation of acts and it also has the power to create resolutions. The former instrument is used for a wide-range of activities, all of them which affect the population at large, whether it is about taxation, sancti-

59 See Wintgens L. Legisprudence. Routledge, Abingdon-on-Thames-New York, 2016, p. 2.

60 See ibid. 5.

61 See ibid. 3.

62 See ibid. 3-4.

63 Jerzy Wróblewski (1926-1990) was one of the most original and most influential legal thinkers of Poland and the whole EasternEuropean jurisprudence. 
oning behaviour considered to be harmful to the society, or even the compensation of a large group of people. ${ }^{64}$ The role of resolutions is two-fold. They are mainly used for program-like declarations for future legislative activities, or to regulate the inner workings of the Parliament itself. Thus, if the Parliament wished to commemorate a past event in history, it would be more advisable to pass a resolution, but if they also wanted to attach some other effect to it, then it should be done through by making an act.

Another example for demonstrating the importance of choosing the right instrument would be the procedures of the US Congress. According to its rules, both Houses are allowed to create public or private bills. Public bills are meant to affect the whole population, whereas private bills are more concerned with a limited number of individuals or private entities. ${ }^{65}$ Thus, for example, it would be a grave mistake for the US Congress if they decided about the compensation of one or few particular individuals through a public bill. But, however, if the scope of affected individuals or entities is much larger, it must be done through a public bill.

Another field Wróblewski identified was the so-called "genuine" field of optimisation. It means that the legislator is in possession of all the required and relevant facts (maximum knowledge) for legislation and is also willing to put it into application. Reforming the tax system serves a good example. The goal is to create a just and efficient tax system, however, in the words of Csaba Szilovics, ${ }^{66}$ "there is no one regal way" ${ }^{67}$ of doing so as optimal tax systems do not exist in real life. ${ }^{68}$ Many factors need to be considered, including willingness to pay taxes, the current level of redistribution, the goals of the state, etc. ${ }^{69}$ But knowledge does not only include facts, but also the knowledge about the relevant laws so that unnecessary legislation could be avoided.

The third field Wróblewski identified is the "praxeological" field of legislation, which he equates with the "correctness" of legislation. The meaning of correctness is twofold. An enacted law can be correct from a moral point of view, as in it was based on strong moral convictions and the intended effect is within good morals. However, correctness can be defined from a legal technical point of view as well.

Further elaborating on the correctness of legislation it must be noted that legal policy is required to ensure the legislation meets the criteria for correctness. The aim of the legal policy is to filter political ends finding which ones are feasible and absolutely necessary for the legi-

64 For example, the investors affected by the Quaestor scandal in Hungary - the collapse of a brokerage firm resulting from poor corporate governance and bad business decisions - were compensated by the state in an Act of Parliament. However, the Act was challenged on constitutional grounds. The act was found to be discriminatory against those who were harmed by similar brokerage firm collapses in the same period, as they were not compensated. See Csaba Szilovics, 'A Magyar Alkotmánybiróság Határozata A Quaestor-Károsultak Kárrendezését Biztosító Követeléskezelő Alap Létrehozásáról’ Kodifikáció és Közigazgatás, Vol. 3 , No. 2, 2015, p. 4.

65 See Visegrády, op. cit., note 40, p. 16.

66 Associate Professor, University of Pécs, Faculty of Law, Financial Law Department.

67 See Csaba Szilovics, 'Az Optimális Adórendszer Feltételeirổl', Adózási pénzügytan és államháztartási gazdálkodás: Közpénzügyek és Államháztartástan II. (ed Csaba Lentner, NKE Szolgáltató Kft 2015). pp. 281-310.

68 See ibid.

69 See Csaba Szilovics, Betrug Und Rechtsbefolgung Im Steuerrecht, Schenk Verlag, 2014, pp. 136-160. 
slature to act on, and which ones should be ignored..$^{70}$ This goes against the usual (and rather imprecise) definition which defines legally policy nothing but political ends and means in law.

\section{EVALUATION OF THE ACT}

Unfortunately, all the pitfalls outlined in the previous section of the paper could be identified in the creation of the Sarbanes-Oxley Act which makes it the target of much criticism since its enactment. Most are targeting the perceived hastiness and unprofessionalism of the legislation which - according to the critiques - were the direct result of the media frenzy generated by the corporate scandals, and the pressure of the public and the political considerations. ${ }^{71}$

Section 402 on prohibiting of directors' loans serves as a great example. Such loans were normally issued for legitimate reasons, such as helping the directors' relocation, advancing their legal fees, or helping them to obtain stock options in the company which in turn creates an incentive for the executive officer to work harder and better. While people like Bernie Ebbers, the CEO of WorldCom, exploited personal loans to a great degree, the overwhelming majority of the corporations operating in the USA such abuse did not happen. Jayne W. Barnard ${ }^{72}$ argues that the outright prohibition of directors' loans was an overreaction from the legislators, which was mostly fuelled by populist sentiments. ${ }^{73}$ The evidence of such populist sentiments can also be found in the spirit of SOX. The problem is, the Act is taking the activities of fraudulent corporations as a starting point. Considering Wróblewski's ideas on genuine optimisation, the legislator seemingly acted without all the knowledge necessary. While at a first glance such approach might have the proper deterrence, it does not meet the criteria for optimal legislation as if fails to take into account that most businesses operated honestly. ${ }^{74}$ Thus, Section 402 fails to meet the standards of optimal legislation on many counts.

It was also objected with regard to the contents of the Act that at many points it only repeats (or emphasises) provisions that are already included in other laws. Therefore SOX means no real reforms, and according to critical professional viewpoints, it only reorganises the previous rules on investor protection, corporate governance and accounting. The supporters of the Act, however, consider the SOX as significant as the securities and capital markets reforms in the 1930 s in the United States. ${ }^{75}$ Having duplicate provisions also increases uncertainty, especially when there are slight differences in their content. Thus, - borrowing Wróblewski's thoughts once again - praxeologically the Act itself is far from optimal. Even if the legislators were guided by the right intention (morally correct) the technical errors committed are negatively affecting the text itself.

\footnotetext{
$70 \quad$ See Visegrády, op. cit., note 40, p. 88.

71 See Romano, op. cit., note 15, pp. 1521-1611.

72 James Goold Cutler, Professor of Law at The College of William \& Mary. She is specialised in corporations and securities reforms.

73 See Barnard, op. cit., note 25, p. 350.

74 See Kecskés; Halász, op. cit., note 1, pp. 213-214.

75 See Elisabeth Bumiller 2002: Corporate Conduct: The President; Bush Signs Bill Aimed at Fraud In Corporations The New York Times July 31. http://www.nytimes.com/2002/07/31/business/corporate-conduct-the-president-bush-signs-bill-aimed-atfraud-in-corporations.html (October 5, 2015).
} 
Due to the hasty nature of the legislation process, the proper attention was not given to the text of the bill, thus the approved Act contained duplicate provisions on sentencing which was likely to cause confusion as their phrasing were ambiguous. ${ }^{76}$ From a legislative point of view, this error is a cardinal sin. Even more of a problem was that seemingly the lawmakers were not familiar with the changes in the Sentencing Guidelines made in 2001 which already increased the penalties for white-collar crimes ${ }^{77}$ which in turn resulted in a hike concerning the minimum and the maximum penalties in $2003,{ }^{78}$ which turned the sentencing mechanisms of economic crimes into a "one-way upward ratchet" as there was no room for downward adjustment. ${ }^{79}$ Whether this was an oversight or a deliberate action by the legislature, regardless it marks SOX as a suboptimal legislation.

The Act is also criticised from another angle with regard to Section 404. The obligations relating to the internal control regulation cause immense costs annually, while they also result in a profit increase for audit firms. Thus, an extra cost is charged on the companies that bring down their efficiency. On the other hand, these costs practically mean considerable profit for those audit firms that were involved in the corporate scandals.

Members of the business world also complained about the five-year rotation of audit firms, as they consider the rule unrealistic. Critics claim that it results in an unnecessary stalling in the course of an audit, moreover, at the top of the business sphere, there are commitments of several directions between the issuers and the auditors, which makes the switching of auditors an uncomfortable formality.

Compliance with the Act and the related costs disproportionately encumber the smaller listed corporations the most. These companies and the Chamber of Commerce representing them criticise the Act for making them pay for the sins committed by large corporations at the turn of the millennium. The major corporations and their representative organisation, the Business Roundtable, show more willingness to comply with the Act, demonstrating how they distance themselves from the companies that were involved in the corporate scandals.

\section{CONCLUSIONS}

The Sarbanes-Oxley Act was more of a reaction to the headlines rather than a principled legislation with the aim of setting standards for the future. This is evidenced by the fact that most of the provisions were simply reactions towards the then trending topics in the media. Another major problem was that there was this great incentive for parties to look tough on corporate crime to make themselves more marketable. This resulted in making overly strict regulations, which made getting listed on American stock exchanges less attractive for smaller and foreign businesses.

\footnotetext{
76 Bowman, F. O, Pour encourages les autres? The Curious History and Distressing Implications of the Sarbanes-Oxley Act and the Sentencing Guidelines Amendments That Followed, Ohio State Journal of Criminal Law, Vol. 1, No. 2, 2003-2004, pp. 408-409.

77 Ibid.p. 375 .

$78 \quad$ Ibid. p. 432.

79 Ibid. pp. 439-440.
} 
Yet it does not mean that corporate governance reforms with legislation are a lost cause. The Act itself closed some serious loopholes which were ripe for abuse, such as resolving the conflict of interest in the auditor profession. The main conclusion that could be drawn from the events is that finding the right instrument for resolving a problem is a key issue. Some of the problems (such as the resolution of the conflict of interest between auditors and corporations) could not have been resolved by other means (a "comply or explain" based code may not have been powerful enough to deter such behaviour).

\section{REFERENCES}

1. Bárczi Judit; Zéman Zoltán; Tóth Márk; Széles Zsuzsanna, Key indices of financial controll, Journal of International Scientific Publication: Economy and Business Vol 2, No 1.

2. Barnard, Jayne W., Historical Quirks, Political Opportunism, and the Anti-Loan Provision of the Sarbanes-Oxley Act, Ohio Northern University Law Review, Vol 31, (2005) 337.

3. Borzán A.; Lentner Cs.; Szigeti C., A pénzügyi vállalkozások felelősségvállalásának új dimenziói 2011 Economica (Szolnok) Vol. 4., No. 11. 2011, pp. 22-30.

4. Bowman, Frank O. III., Pour encourages les autres? The Curious History and Distressing Implications of the Sarbanes-Oxley Act and the Sentencing Guidelines Amendments That Followed, Ohio State Journal of Criminal Law, 1 (2003-2004) 408-409.

5. Hill, H., Einführung in die Gesetzgebungslehre. C. F. Müller Juristicher Verlag Heidelberg 1982, 2; cited by Drinóczi, Tímea, Petrétei, István: Jogalkotástan. Dialóg-Campus Kiadó. Pécs, 2004, 17.

6. House of Representatives, How Our Laws are Made: Revised and Updated, 2007, 36-37.

7. Kecskés, András, Halász, Vendel, Stock Corporations A Guide to Initial Public Offerings, Corporate Governance and Hostile Takeovers Budapest, 2013, p. 566.

8. Kim, Brian, Recent Developments, Harvard Journal on Legislation, 40 (Winter 2003) 238.

9. Lentner Cs.; Szegedi K.; Tatay T., Corporate Social Responsibility in the Banking Sector, Pénzügyi Szemle/Public Finance Quarterly Vol. 60, No. 1, 2015, pp. 95-103.

10. Lentner, Cs., A pénzintézetek társadalmi felelősségvállalásának új dimenziói és a könyvvizsgálat szerepe, Számvitel adó könyvvizsgálat: szakma Vol. 53, No. 7-8, 2011, pp. 348-350.

11. Lukács, János, Tóth, Márk, Zéman Zoltán, A számviteli politika döntéstámogatásának modellezése ágazati mátrix fejlesztéssel Gazdaság és társadalom Vol. 12, No. 3-4, 2012, pp. 106-117.

12. Romano, Roberta, The Sarbanes-Oxley Act and the Making of Quack Corporate Governance, Yale Law Journal 114, 2004-2005, 1551.

13. Sándor, István, A bizalmi vagyonkezelés és a trust, Budapest 2014, 233.

14. Schulze-Fielitz, T., Theorie und Praxis parlamentarischer Gesetzgebung. Duncker \& Humblot. Berlin, 1988. 1. cited by Drinóczi, Tímea, Petrétei, István: Jogalkotástan. Dialóg-Campus Kiadó. Pécs, 2004, 17.

15. Seidman, Robert, Justifying Legislation: A Pragmatic, Institutionalist Approach to the Memorandum of Law, Legislative Theory, and Practical Reason, Harvard Journal on Legislation 29 (1992) 76.

16. Szilovics, Csaba, 'A Magyar Alkotmánybíróság Határozata A Quaestor-Károsultak Kárrendezését Biztositó Követeléskezelő Alap Létrehozásáról' (2015) 4 Kodifikáció és Közigazgatás. 
17. Szilovics, Csaba, 'Az Optimális Adórendszer Feltételeiről', Adózási pénzügytan és államháztartási gazdálkodás: Közpénzügyek és Államháztartástan II. (ed Csaba Lentner, NKE Szolgáltató Kft 2015). pp. 281-310.

18. Szilovics, Csaba, Betrug Und Rechtsbefolgung Im Steuerrecht (1st edn, Schenk Verlag 2014). pp. 136-160.

19. Visegrády, Antal, The Influence of Jerzy Wróblewski on Hungarian Legal Theory, Prawo I Politika 7. 96.

20. Waldron, Jeremy, The Dignity of Legislation, Maryland Law Review Vol. 54, No. 2, 646-647.

21. Wintgens, Luc: Legisprudence. Routledge, Abingdon - New York, 2016, 2.

22. Zéman, Zoltán.; Gacsi Roland; Lukács János; Hajós László, Management control system in banks, BIATEC, Vol. 21, No. 6, 2013, pp. 14-17.

\section{LIST OF REGULATIONS, ACTS AND COURT DECISIONS}

1. 148 Cong. Rec. 2002 1,548 April 24 (statement of Mr Jones).

2. 148 Cong. Rec. 2002 H1541 April 24 (statement of Mr Sessions).

3. 148 Cong. Rec. 2002 H1546 April 24 (statement of Mr Kanjorski).

4. 148 Cong. Rec. S6332 July 8th (statement of Senator Sarbanes).

5. H.R 3763. as engrossed in House (04/24/2002).

6. House of Representatives: Conference Report July 24, 2002. (H. Rept. 107-610) 69.

7. See 148 Cong. Rec. 2002 H1546 April 24 (statement of Mr LaFalce).

8. See 148 Cong. Rec. 2002 H1552 April 24 (statement of Mr Ferguson).

\section{WEBSITE REFERENCES}

1. Bumiller, Elisabeth 2002: Corporate Conduct: The President; Bush Signs Bill Aimed at Fraud In Corporations The New York Times July 31. http://www.nytimes.com/2002/07/31/business/corporateconduct-the-president-bush-signs-bill-aimed-at-fraud-in-corporations.html (October 5, 2015).

2. Cummings, Jeanne -Dreazen, Yochi -Schroeder, Michael 2002: SEC Chairman Pitt Resigns Amid Webster Controversy The Wall Street Journal November 6. http://www.wsj.com/articles/ SB1036548136249093108 (October 5, 2015).

3. Library of Congress: The Legislative Process: Resolving Differences Congress.gov https://www.congress.gov/legislative-process/resolving-differences (October 5, 2015).

4. The President's 10-Point Plan - Improving Corporate Responsibility And Protecting America's Shareholders Wall Street Journal March 6, 2002, http://www.wsj.com/articles/SB1015460971646141720 (October 5, 2015).

5. United States Senate, Senate History 1964-Present The Unforgettable 107th Congress http://www. senate.gov/artandhistory/history/minute/unforgettable-107th-congress.htm (October 5, 2015). 


\section{REFORMA KORPORATIVNOG UPRAVLJANJA PREKO ZAKONODAVSTVA U SJEDINJENIM AMERIČKIM DRŽAVAMA - SLUČAJ SARBANES-OXLEYEVA ZAKONA}

\section{Sažetak}

Ovaj se rad bavi analizom Sarbanes-Oxleyeva zakona s teorijsko-zakonodavnog aspekta kroz prezentiranje nekih zakonodavnih teorija, područja kojemu se u novije vrijeme poklanja više pozornosti u angloameričkoj sudskoj praksi. Namjera je autora uspoređivanjem s nekim normativnim teorijama dokazati da Sarbane-Oxleyev zakon pripada suboptimalnim zakonskim rješenjima.

Ključne riječi: $\quad$ Sarbanes-Oxleyev zakon, optimalni zakoni, donošenje zakona, funkcionalnost zakona, učinkovitost zakona

\section{(i)}

This work is licensed under a Creative Commons

Attribution-NonCommercial 4.0 International License.

* $\quad$ Dr. sc. András Kecskés, izvanredni profesor na Katedri za poslovno i trgovačko pravo, Pravni fakultet, Sveučilište u Pečuhu. H-7622 Pécs, 48-as tér1., Republika Mađarska. Adresa e-pošte: kecskes.andras@ajk.pte.hu. ORCID: http://orcid.org/0000-00016158-2049. 
